\title{
Use of active games for the development of general and special physical training of young volleyball players
}

\author{
Boltayev Zayniddin Boltayevich ${ }^{1}$, Komil Juraqulovich Norboyev ${ }^{2}$, Qurbonova I. ${ }^{3}$ \\ ${ }^{I}$ Professor of Samarkand state university, Uzbekistan \\ ${ }^{2}$ Associate professor of Samarkand state university, Uzbekistan \\ ${ }^{3}$ Master of Samarkand state university, Uzbekistan
}

Email: N-komiljon@samdu.uz

\begin{abstract}
This article is based on the experience of using play games to develop the overall and specific physical fitness of young people and youth volleyball players.

Keywords: Exercise, Physical Training, Diving, Active Games, Effectiveness, Rehearsals.

\section{INTRODUCTION}

Upbringing a healthy and harmoniously developed generation is one of the priority directions of the state policy. At the present stage of development of the society, training of young athletes is of particular importance. M.A. Godick (1999) L.R. Ayrapetyans (2006), AAPulatov (2012), Sh.Kh.Isroilov (2014), M. Kurbonova (2010) Meliev X (2004), including foreign scientists VMZatsiorsky (1995), LPMatvyev (1997), VN Sokolov (1999), David Lavallee, John Kremer (2004), Edmunds J, Ntoumani N (2006), V. Yegnateva, AV Ignatev AA conducted research work in 2015 (2015). Physical training plays an important role in achieving high sports results. Therefore, it is important to pay special attention to the development of general and special physical training of volleyball players. Therefore, the emphasis on developing a general and special physical training of young volleyball players during the course is the key to achieving high results in sports. Consequently, one of the key issues is to prove the effectiveness of physical training methods in the training process.

Purpose of the study: Use of active games for the development of general and special physical training of young volleyball players.

Research objectives: To study the effectiveness of using active games in the development of young volleyball players.

Scientific novelty of the study: There is a scientific basis for the effectiveness of the use of mobile games for the training of young volleyball players.

Match games are categorized according to their practicality. Many moving games often have practical behaviors because of their traditional lives. Some of them have the potential to become recognized as sports or play games. [1] In addition, some games can be regarded as fundamentally prepared, especially for sports, and can serve as a way for children to choose different sports clubs. Of course, it is impossible to determine the pedagogical content and importance of moving games without considering the agespecific features of moving games in terms of their use.

Development, analysis and illustration of research materials. The children of the control group have been engaged in a voluntary volleyball program for a year and a half on a commonly accepted (traditional) curriculum for coaches at the children's and youth's sports school in Samarkand. It was important for children who were selected using the game tests to determine how the game's talents were displayed as a result of the behavioral tests they identified.

The research team is unique in that each of the exercises in the pedagogical study is supplemented with specially selected moving games, including moving games that resemble the basic volleyball movements and their variants. is calculated.
\end{abstract}


In the study group, the total amount of active games used by the training program was increased by $65.5 \%$ while maintaining the number of individual cycles and hours.

Table 1. Classification of action games by the name of the moving game (1), its structure, its influence on the development of gaming skills (2), its type, structure, plot (3)

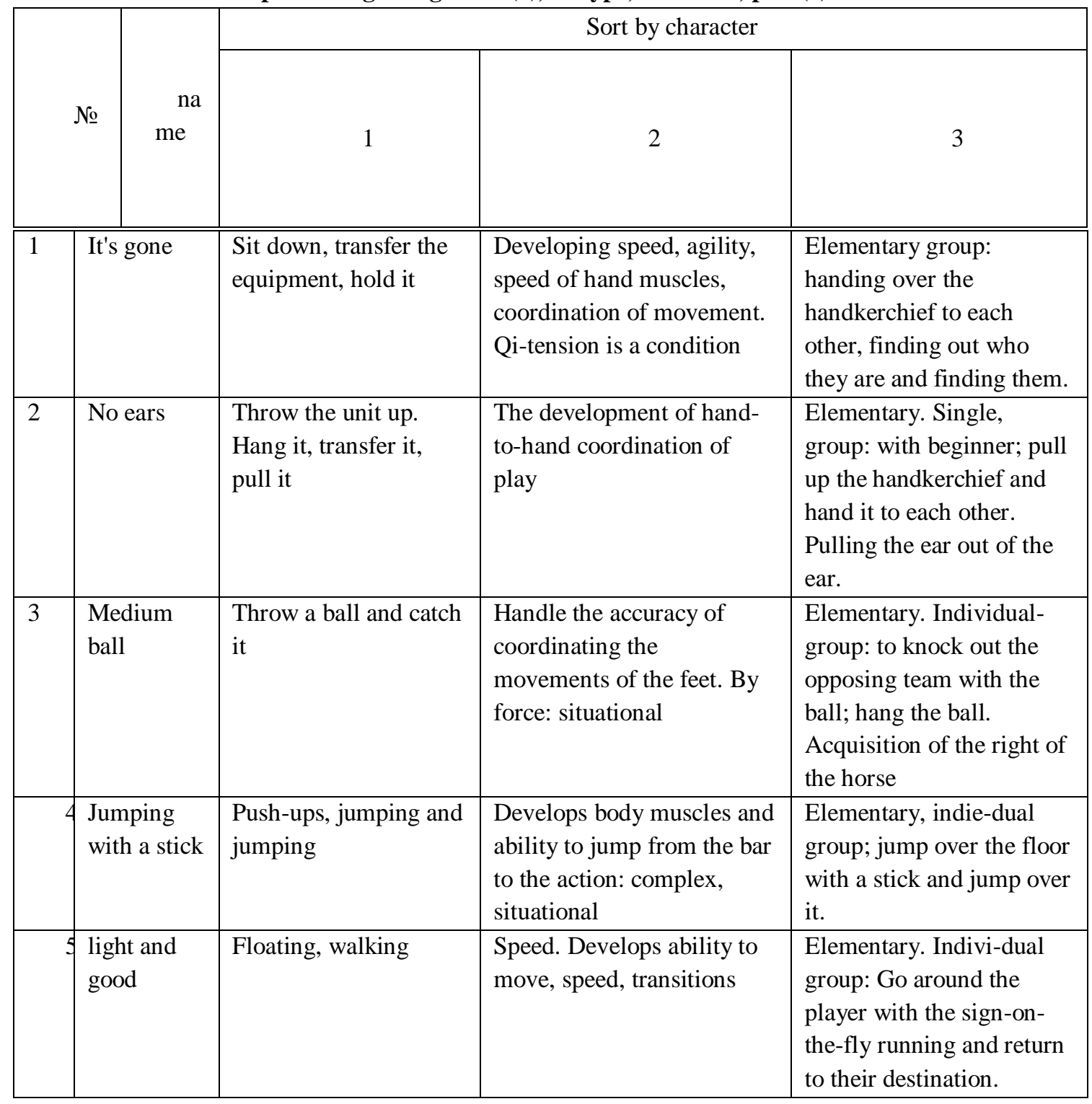

Table 2. action games (1), structure, impact icons (2), motor skills (3), activities, action games, sports similarities (4)

\begin{tabular}{|c|c|c|c|c|c|}
\hline \multirow{2}{*}{${ }^{\mathrm{T}}$} & \multirow[t]{2}{*}{ Name } & \multicolumn{4}{|c|}{ Sort by character } \\
\hline & & 1 & 2 & 3 & 4 \\
\hline 1 & Granata & $\begin{array}{l}\text { Shooting, } \\
\text { throwing, } \\
\text { shooting }\end{array}$ & $\begin{array}{l}\text { Hand muscles } \\
\text { Motivation of the } \\
\text { cochlear, causing the } \\
\text { disturbance: use of } \\
\text { force; }\end{array}$ & & $\begin{array}{l}\text { Volleyball is a } \\
\text { sport }\end{array}$ \\
\hline 2 & Walking & Walking & $\begin{array}{l}\text { Develops the muscles } \\
\text { of the hand: speed and } \\
\text { strength, develops the } \\
\text { muscles of the foot; }\end{array}$ & $\begin{array}{l}\text { Developme } \\
\text { nt of } \\
\text { walking } \\
\text { skills }\end{array}$ & $\begin{array}{l}\text { Volleyball is a } \\
\text { sport }\end{array}$ \\
\hline 3 & "Jumping on a & Running, & Develops muscles, & & Volleyball is a \\
\hline
\end{tabular}




\begin{tabular}{|c|c|c|c|c|c|}
\hline & $\begin{array}{l}\text { hanging } \\
\text { device", }\end{array}$ & $\begin{array}{l}\text { jumping, } \\
\text { stretching your } \\
\text { arms }\end{array}$ & $\begin{array}{l}\text { coordination of } \\
\text { movement, ability to } \\
\text { move; velocity-force. }\end{array}$ & & sport \\
\hline 4 & $\begin{array}{l}\text { "Jump on a } \\
\text { whip" }\end{array}$ & $\begin{array}{l}\text { Jump over } \\
\text { obstacles }\end{array}$ & $\begin{array}{l}\text { Leg muscles. Promotes } \\
\text { calmness, strength, } \\
\text { endurance }\end{array}$ & $\begin{array}{l}\text { Develop a } \\
\text { skill for } \\
\text { overcoming } \\
\text { obstacles }\end{array}$ & $\begin{array}{l}\text { Volleyball is a } \\
\text { sport }\end{array}$ \\
\hline 5 & $\begin{array}{l}\text { "Sequential } \\
\text { jumping and } \\
\text { backward } \\
\text { movement" }\end{array}$ & Jump backward & $\begin{array}{l}\text { Development of leg } \\
\text { muscles; use of force; } \\
\text { the situation }\end{array}$ & & $\begin{array}{l}\text { Volleyball is a } \\
\text { sport }\end{array}$ \\
\hline 6 & Going forward & $\begin{array}{l}\text { Sitting, bending } \\
\text { forwards, } \\
\text { bending. Push-ups } \\
\text { from head to toe }\end{array}$ & $\begin{array}{l}\text { The hand, legs, body } \\
\text { develops movement, } \\
\text { balance, speed, } \\
\text { strength, position }\end{array}$ & & $\begin{array}{l}\text { Volleyball is a } \\
\text { sport }\end{array}$ \\
\hline 7 & $\begin{array}{l}\text { Jump on one } \\
\text { foot }\end{array}$ & $\begin{array}{l}\text { Jump on one foot } \\
\text { with the ball }\end{array}$ & $\begin{array}{l}\text { Stimulates the muscles } \\
\text { of the feet, the } \\
\text { coordination of their } \\
\text { movements, and the } \\
\text { balance of their } \\
\text { movements; use of } \\
\text { force; the situation }\end{array}$ & & $\begin{array}{l}\text { Volleyball is a } \\
\text { sport }\end{array}$ \\
\hline
\end{tabular}

The study of physical fitness and growth rates is important for scheduling long-term workouts and selecting tools and techniques for young athletes, depending on their age and individual characteristics. [2] Determining the level and dynamics of junior volleyball training also allows evaluating the work of coaches. The information obtained allows you to make timely adjustments to your workouts.

The level of physical training is of great importance for further training of the young athlete, including for the stage of sports competitions [3]. In order to determine the level of physical training of young volleyball players, they were subjected to supervisory tests in accordance with the current program. Table 3 presents the results of the volleyball tests for boys volleyball boys on admission to the primary training groups.

Analyzing the data obtained, boys have a good rating of 30 yards, jump up and down, run and jump, and throw balls while standing. matched the coin. Running $6 \times 5 \mathrm{~m}$ with a change of direction and throwing the ball into the ball was lower than the "satisfactory" rating.

Table 3. The results of the physical training of young volleyball players.

\begin{tabular}{|l|c|c|c|}
\hline Tests & $\begin{array}{c}\text { gende } \\
\mathrm{r}\end{array}$ & $\overline{\mathrm{X}}$ & $\delta$ \\
\hline Running 30 meters from high stat (Sec). & men & 6,6 & 0,758 \\
\hline Toggle Route 6x5 m / s & men & 12,92 & 0,971 \\
\hline Jump up height (cm) & men & $\begin{array}{l}163,4 \\
8\end{array}$ & 17,225 \\
\hline Jump up and jump, (cm) & men & 31,23 & 4,374 \\
\hline Running and jumping in length (cm) & men & 38,14 & 5,315 \\
\hline $\begin{array}{l}\text { Throwing the fill ball (1kg) behind the head with } \\
\text { both hands: sitting (m / cm). }\end{array}$ & O' & 3,35 & 0,732 \\
\hline Standing (m / cm). & O' & 8,48 & 2,024 \\
\hline Jumping (m / cm). & & 7,54 & 1,772 \\
\hline
\end{tabular}

Note: - boys ( $p$-109

This section presents the results of a study of how young volleyball teams of control and research teams change their physical performance. As we mentioned, the methods used in the control and research group included participants selected by physical activity tests using physical activity tests. 
Pupils of the control group are currently involved in the volleyball program at the Samarkand Children's Sport and Athletics School. In this case, the task of the study was to determine how effective a test game was with respect to the mass sampling method used during the experiment. The research team is focusing on the structure of the main activities of the youth volleyball team during the training, along with the tools and techniques provided in the curriculum of the Youth Sports School for Children and Athletics in Samarkand. It was used in special volleyball games that were similar to the main actions in volleyball. The task was to find out how well selected specially designed games would have different effects on the training of young players. The physical training was studied three times during one and a half years of pedagogical experience: at the beginning of the study (December 2018), at the end of the first year, it was conditionally labeled as 'experiential learning' and at the end of the second year. Tables 5 - 5 show the results of the control of the level of physical training of young volleyball players in the control group during the pedagogical study.

By the end of the first year of training, the boys' test results were below the test requirements, but only when the ball was thrown in the normal position. 'he said. By the end of the second year of training, it was appropriate to run the program and change the direction of the program and toss the paddle (1 kg) with both hands. Other indicators were slightly lower than the baseline grading tests during the initial training period. Table 4

Dynamics of physical training of young volleyball players in the control group during pedagogical research $(\bar{X} \pm \delta)$

\begin{tabular}{|c|c|c|c|c|c|c|}
\hline Tests & 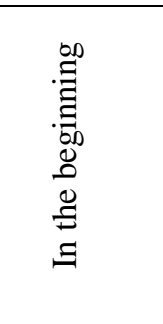 & 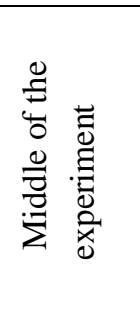 & 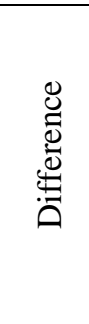 & 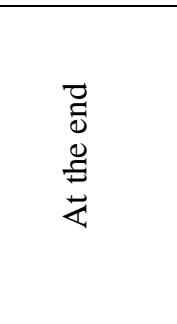 & 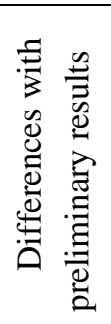 & $\simeq$ \\
\hline $\begin{array}{l}\text { Running } 30 \mathrm{~m} \text { from } \\
\text { top start }(\mathrm{sec})\end{array}$ & $\begin{array}{l}5,61 \pm 0,41 \\
8\end{array}$ & $\begin{array}{l}5,38 \pm 0 \\
427\end{array}$ & 0,23 & $5,23 \pm 0,413$ & $-0,38$ & $\begin{array}{l}<0, \\
05\end{array}$ \\
\hline $\begin{array}{l}\text { Toggle track } 6 \times 5 \mathrm{~m} \\
(\mathrm{sec})\end{array}$ & $\begin{array}{l}12,51 \pm 0,6 \\
71\end{array}$ & $\begin{array}{l}12,05 \pm 0 \\
662\end{array}$ & $\begin{array}{r}- \\
0,46\end{array}$ & $\begin{array}{c}11,68 \pm 0,72 \\
1\end{array}$ & $-0,83$ & $\begin{array}{l}<0, \\
05\end{array}$ \\
\hline $\begin{array}{l}\text { Jump from place to } \\
\text { length }\end{array}$ & $\begin{array}{l}176,49 \pm 5 \\
314\end{array}$ & $\begin{array}{l}182,08 \pm \\
6,189\end{array}$ & 59 & $\begin{array}{l}191,83 \pm 5,7 \\
74\end{array}$ & $\begin{array}{l}15,3 \\
4\end{array}$ & $\begin{array}{l}<0, \\
05\end{array}$ \\
\hline $\begin{array}{l}\text { Jump from the floor } \\
\text { to the heights }\end{array}$ & $\begin{array}{l}37,08 \pm 2,1 \\
12 \\
\end{array}$ & $\begin{array}{l}41,33 \pm 2 \\
, 124 \\
\end{array}$ & 25, & $\begin{array}{l}46,42 \pm 2,24 \\
5 \\
\end{array}$ & 9,33 & $\begin{array}{c}<0, \\
01\end{array}$ \\
\hline $\begin{array}{l}\text { Run around and } \\
\text { jump high }\end{array}$ & $\begin{array}{l}44,83 \pm 2,4 \\
17\end{array}$ & $\begin{array}{l}49,10 \pm 2 \\
508\end{array}$ & $\begin{array}{r}4, \\
27\end{array}$ & $\begin{array}{l}53,91 \pm 2,61 \\
2\end{array}$ & 9,08 & $\begin{array}{l}<0, \\
01\end{array}$ \\
\hline $\begin{array}{l}\text { Fill the ball }(1 \mathrm{~kg}) \\
\text { with both hands } \\
\text { behind the head }\end{array}$ & $\begin{array}{l}4,78 \pm 0,53 \\
4\end{array}$ & $\begin{array}{l}5,22 \pm 0 \\
612\end{array}$ & $44^{0,}$ & $6,14 \pm 0,594$ & 1,36 & $\begin{array}{l}<0, \\
01\end{array}$ \\
\hline Standing & $\begin{array}{l}9,92 \pm 1,25 \\
9\end{array}$ & $\begin{array}{l}10,77 \pm 1 \\
, 323\end{array}$ & 85 & $\begin{array}{c}11,83 \pm 1,19 \\
2\end{array}$ & 1,91 & $\begin{array}{l}<0, \\
01\end{array}$ \\
\hline By jumping & $\begin{array}{l}8,25 \pm 1,23 \\
7\end{array}$ & $\begin{array}{l}8,82 \pm 1 \\
117\end{array}$ & 57 & $9,63 \pm 1,219$ & 1,38 & $\begin{array}{l}<0, \\
01\end{array}$ \\
\hline
\end{tabular}

Running and jumping from 30 yards to a high start, the results of the test were equal to the program requirements and the rest were below the program requirements.

In Table 5, the test team's students use the results of their test scores with the same criteria as the size of the first academic year (the middle of the experiment) from grade to grade and the two-year graduation requirements. Table 5

Dynamics of physical education of young volleyball players in the research group during pedagogical research $(\bar{X} \pm \delta)$ 


\begin{tabular}{|c|c|c|c|c|c|c|}
\hline Tests & $\begin{array}{l}\underbrace{\infty}_{\Xi} \\
. \Xi \\
.0 \\
0 \\
0 \\
0 \\
\Xi \\
\Xi \\
\Xi\end{array}$ & 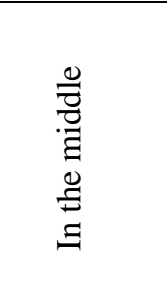 & 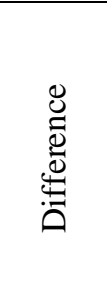 & 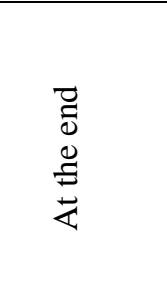 & 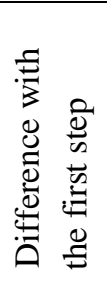 & $\simeq$ \\
\hline $\begin{array}{l}\text { Running } 30 \mathrm{~m} \text { from } \\
\text { top start }(\mathrm{sec})\end{array}$ & $\begin{array}{c}5,68 \pm 0,47 \\
1\end{array}$ & $\begin{array}{l}5,30 \pm 0,45 \\
2\end{array}$ & 0,38 & $\begin{array}{l}5,11 \pm 0,42 \\
6\end{array}$ & $\begin{array}{r}- \\
0,57\end{array}$ & $\begin{array}{l}<0,0 \\
1\end{array}$ \\
\hline $\begin{array}{l}\text { Toggle Lane } \\
\text { Attachment } 6 \times 3 \mathrm{~m} \\
(\mathrm{sec})\end{array}$ & $\begin{array}{l}12,46 \pm 0,6 \\
89\end{array}$ & $\begin{array}{l}11,78 \pm 0,6 \\
10\end{array}$ & 0,68 & $\begin{array}{l}11,30 \pm 0,5 \\
84\end{array}$ & 1,16 & $\begin{array}{l}<0,0 \\
1\end{array}$ \\
\hline $\begin{array}{l}\text { Jump from place to } \\
\text { length }\end{array}$ & $\begin{array}{l}175,83 \pm 5 \\
615\end{array}$ & $\begin{array}{l}185,20 \pm 5 \\
335\end{array}$ & $\begin{array}{l}3,3 \\
7\end{array}$ & $\begin{array}{l}198,11 \pm 5 \\
014\end{array}$ & $\begin{array}{l}22,2 \\
8\end{array}$ & $\begin{array}{l}<0,0 \\
1\end{array}$ \\
\hline $\begin{array}{l}\text { Jump from the } \\
\text { floor to the heights }\end{array}$ & $\begin{array}{l}36,50 \pm 2,1 \\
76\end{array}$ & $\begin{array}{l}42,68 \pm 2,2 \\
37\end{array}$ & $\begin{array}{l}6,1 \\
8\end{array}$ & $\begin{array}{l}49,59 \pm 2,1 \\
18\end{array}$ & $\begin{array}{l}13,0 \\
9\end{array}$ & $\begin{array}{l}<0,0 \\
1\end{array}$ \\
\hline $\begin{array}{l}\text { Run around and } \\
\text { jump high }\end{array}$ & $\begin{array}{l}43,83 \pm 2,5 \\
12\end{array}$ & $\begin{array}{l}50,04 \pm 2,4 \\
44\end{array}$ & $\begin{array}{l}6,2 \\
1\end{array}$ & $\begin{array}{l}56,94 \pm 2,3 \\
87\end{array}$ & $\begin{array}{l}13,1 \\
1\end{array}$ & $\begin{array}{l}<0,0 \\
1\end{array}$ \\
\hline $\begin{array}{l}\text { Fill the ball }(1 \mathrm{~kg}) \\
\text { with both hands } \\
\text { behind the head } \\
\text { while sitting }\end{array}$ & $\begin{array}{l}4,59 \pm 0,57 \\
1\end{array}$ & $\begin{array}{l}5,50 \pm 0,54 \\
5\end{array}$ & $\begin{array}{l}0,9 \\
1\end{array}$ & $\begin{array}{l}6,48 \pm 0,51 \\
3\end{array}$ & 1,89 & $\begin{array}{l}<0,0 \\
1\end{array}$ \\
\hline Standing & $\begin{array}{l}9,81 \pm 1,34 \\
3\end{array}$ & $\begin{array}{l}10,95 \pm 1,2 \\
89\end{array}$ & $\begin{array}{l}1,1 \\
4\end{array}$ & $\begin{array}{l}12,24 \pm 1,2 \\
09\end{array}$ & 2,43 & $\begin{array}{l}<0,0 \\
1\end{array}$ \\
\hline By jumping & $\begin{array}{c}8,17 \pm 1,27 \\
3\end{array}$ & $\begin{array}{l}9,19 \pm 1,21 \\
5\end{array}$ & $2^{1,0}$ & $\begin{array}{l}10,38 \pm 1,2 \\
23\end{array}$ & 2,21 & $\begin{array}{l}<0,0 \\
1\end{array}$ \\
\hline
\end{tabular}

Differences in the level of preparation for the second test group in these groups were significantly higher than $r<0.01$ for $r<0.001$ and higher than those of the other tested groups.

Different groups in the tables show that in the first year of volleyball and in the second year, many factors are influenced by the factors and, therefore, the speed and speed (running from a high start for 30 meters). 5x6) (Sec)) shows the smallest growth results in areas related to the display. The study groups had the largest advantage of jumping, which is one of the most important qualities in volleyball. The organization of the obtained data shows that, in general, the different dynamics of the dynamics of the preparation process have different rates of growth. For this reason, the dynamics of complex assessment of physical fitness are important. The pedagogical research provides data that reflects the trend towards a change in physical performance. Comparative analysis of baseline data and results obtained at the end of pedagogical research clearly showed that ( $p<0.01-0,001)$ improved physical fitness for both boys and girls in the control group. agreed. Compared to the physical training rate, the study groups had the highest rates for boys. Complex analysis of physical training in young athletes shows that each athlete can draw conclusions about comparing their abilities. For example, it is not feasible to compare the results of running up to 30 meters from a high start, where measurements are done in seconds. It is impossible to do even when jumping. The result is measured in centimeters.

\section{CONCLUSION}

The research team analyzes the results of the physical activity dynamics of the participants, taking into account the characteristics of the selected sport and the physical characteristics that lag behind in developing them. high rates of development and growth. The results show that the level of general and special physical training of the pre-survey control group members did not differ significantly from the survey team members.

At the end of the study, the increase in these indicators did not change significantly. Indicators of general and special physical education, recorded in the study group, have proven the extreme effectiveness of the movement games used in training sessions. 
In both groups, the quality and skills learned during the first six months of training are not very effective. However, the study group found that overall physical and physical training were higher than those in the control group. The play group used in the study group provides not only the general and special physical training level, but also the better performance of other game skills. This situation dictates that the aforementioned special-purpose games should be included in the special exercises.

\section{REFERENCES}

1. M.A Kurbanova The choice of young volleyball players during the initial training and the use of folk games during their training. Dissertation work. Tashkent 2006.

2. A.A Pulatov Technique of formation of speed and strength of young volleyball players // Methodical manual. - T .: 2008. - 38 b.

3. T.S Usmanhojaev, HA Meliev, National Action Games. T: "Teacher," 2000. 53 p. 